\title{
HAEMOLYSIS AS A MEANS OF DISTINGUISHING BETWEEN LEPTOSPIRA INTERROGANS SEROVARS BALCANICA AND HARDJO
}

\section{S. C. Hathaway and R. B. Marshall}

Department of Veterinary Pathology and Public Health, Massey University, Palmerston North, New Zealand

LEPTOSPIRES of the Hebdomadis serogroup have been isolated from a wide range of vertebrate hosts throughout the world (Communicable Diseases Center, 1966 and 1973). Only two serovars, hardjo and balcanica, belonging to this serogroup are known to be present in New Zealand.

Hardjo appears to be maintained by cattle (Johnson, Allan and Dennett, 1974; Ellis and Michna, 1977; Hellstrom, 1978), whereas balcanica has a wider host spectrum. Balcanica is endemic in possums (Trichosurus vulpecula) in New Zealand (Hathaway, Blackmore and Marshall, 1978) and in Australia (Durfee and Presidente, 1977); the original strain, 1627 Burgas, was isolated from a patient in Bulgaria (Babudieri and Mateew, 1961; Manev and Siromashkova, 1970), and subsequent strains were isolated from cattle and pigs in the Soviet Union (Semenova, Soloshenko and Ananyin, 1965).

Balcanica and hardjo are antigenically similar and the infections that they produce are not easily differentiated serologically (Hellstrom, 1978; Hathaway and Marshall, 1979). At present, the usual means of differentiating balcanica and hardjo is agglutinin absorption, which is not a routine procedure in most diagnostic laboratories.

Several serovars of various serogroups are known to be haemolytic; haemolytic activity has not been found in any serovar of the Hebdomadis serogroup (Russell, 1956; Kmety and Bakoss, 1961; Kasărov, 1970; Hodges, 1974) except serovar haemolyticus, strain Marsh (Alexander et al., 1956). This report describes the in-vitro haemolytic activity of balcanica for human, bovine, ovine and possum red blood cells (RBC). This activity may be used as the basis of a simple test for the preliminary differentiation of balcanica and hardjo isolates.

\section{MATERIALS AND METHODS}

Organisms. A total of 14 balcanica and five hardjo strains were tested for haemolytic activity. Except for one hardjo isolate from a human (strain a), all hardjo strains had recently been isolated from cattle; the balcanica isolates were all from possums. Strains were maintained by weekly subculture in liquid EMJH Medium (Difco, Detroit, Michigan, USA). Periodic examinations were made for bacterial contamination. The identities of seven of the balcanica and three of the hardjo strains were subsequently confirmed by agglutinin-absorption tests at the WHO Reference Laboratory, Atlanta, Ga, USA. A pomona isolate from a pig was used as a positive control and a strain of ballum - a non-haemolytic serovar (Russell, 1956) - was used as a negative control. All cultures were aged 7 days and contained at least $10^{7}$ organisms per $\mathrm{ml}$.

Blood-agar plates. Red blood cells (RBC) from humans, cattle, sheep and possums were washed three times in sterile phosphate-buffered saline $(0.85 \%)$. A serum sample from each donor was tested by the microscopic agglutination test (Cole, Sulzer and Pursell, 1973) against live balcanica, ballum, copenhageni, hardjo, pomona and tarassovi; the minimum serum dilution was always 1 in 24 . Each plate $(9 \mathrm{~cm}$ diameter) contained $10 \mathrm{ml}$ of a $5 \%(\mathrm{v} / \mathrm{v})$ suspension of $\mathrm{RBC}$ in Columbia Agar Base (BBL) over $10 \mathrm{ml}$ of Agar Base (Difco) with $0.5 \% \mathrm{NaCl}$ added. Other

Received 29 Oct. 1979; revised version accepted 23 Jan. 1980.

Reprint requests to Dr R. B. Marshall, Dept. of Veterinary Pathology and Public Health, Massey University, Palmerston North, New Zealand. 
plates were similar but contained unwashed RBC. Ten wells were made in each plate by means of a sterile 8-mm cork borer. Plates were used within 3 weeks of preparation.

Plate haemolytic test. Each well was filled with $0.75 \mu \mathrm{l}$ of leptospire culture by means of a graduated automatic pipette fitted with a sterile disposable tip. In each plate one well was filled with $0.75 \mu \mathrm{l}$ of sterile medium. Plates were incubated at $30^{\circ} \mathrm{C}$ for $72 \mathrm{~h}$ in sealed containers. Zones of haemolysis were measured to the nearest $0.1 \mathrm{~mm}$ by means of a measuring magnifier. The measurement was taken from the edge of the well to the edge of the zone of complete haemolysis. Small outer zones of incomplete haemolysis were ignored.

Tube haemolytic test. Seven-day cultures $(5 \mathrm{ml})$ in EMJH medium were rendered isotonic by the addition of $0.42 \mathrm{ml}$ of $10 \% \mathrm{NaCl}$. One $\mathrm{ml}$ of each isotonic culture and $1 \mathrm{ml}$ of $5 \%(\mathrm{v} / \mathrm{v})$ washed human $\mathrm{RBC}$ were incubated at $37^{\circ} \mathrm{C}$ for $18 \mathrm{~h}$ in a sterile glass tube. An osmotic haemolysate $(1.0 \mathrm{ml}$ of $5 \% \mathrm{RBC}$ suspension and $1.0 \mathrm{ml}$ of distilled water) and a culture-medium control (1.0 ml of a $5 \%$ RBC suspension and $1.0 \mathrm{ml}$ of isotonic medium) were incubated with each series of strains tested. After incubation all suspensions were centrifuged; each supernate was diluted with an equal volume of $0.85 \%$ saline, and its optical density read at $540 \mathrm{~nm}$ by means of a spectrophotometer (Bausch Lomb, Spectronic 20).

\section{Results}

The table shows the ability of four strains of balcanica and one positive control (pomona) to haemolyse washed and unwashed RBC from two donors of each of the following species: man, ox, sheep and possum. Two strains of hardjo and one negative control (ballum) were negative; culture-medium controls were completely negative on unwashed $\mathrm{RBC}$ and mainly though not completely negative on washed RBC. In a second experiment the mean haemolytic activity of 14 strains of balcanica and five of hardjo was tested on washed and unwashed RBC from five human and five bovine donors. The mean measurements of the zones of haemolysis (in $\mathrm{mm}$, \pm SD) were as follows: balcanica on washed human and bovine RBC, $1 \cdot 14 \pm 0 \cdot 27$ and $1 \cdot 09 \pm 0 \cdot 28$ respectively; balcanica on unwashed human and bovine $\mathrm{RBC}, 0.82 \pm 0.33$ and $0.11 \pm 0.29$ respectively; hardjo negative on all $\mathrm{RBC}$ preparations except for a slight reaction $(0.06 \pm 0.03)$ on washed bovine RBC. The results for the positive and negative controls (pomona and ballum respectively) were exactly as in the first experiment (see table).

In all, three of six culture-medium controls gave a zone of incomplete haemolysis on washed RBC, and one gave a zone of complete haemolysis; no such reactions occurred on unwashed RBC. RBC from cattle, sheep and possums were much more susceptible in the washed state than in the unwashed state to haemolysis by balcanica. The greater resistance of unwashed $\mathrm{RBC}$ to haemolysis appeared to be associated with antibody to the Hebdomadis serogroup in the sera of donors. However, unwashed RBC from some seronegative donors were partially resistant to haemolysis.

In a tube test, haemolysis of washed human $\mathrm{RBC}$ from three donors, as measured by mean optical density, was tested in respect of six strains of balcanica, five of hardjo, one of ballum, a culture-medium control, and an osmotic haemolysate ( $100 \%$ haemolysis). The results, $\pm \mathrm{SD}$, were respectively $0.61 \pm 0.12,0.11 \pm 0.04,0.07 \pm 0.03$, and $0.87 \pm 0.03$. Reference to a standard curve showed that the percentage haemolysis values for balcanica, hardjo, and culture-medium controls were 70,14 and 19 , respectively.

Repeated testing showed that six strains of balcanica had lost, wholly or partially, their haemolytic activity for human RBC after 52 weekly subcultures.

\section{Discussion}

Haemolytic activity has been demonstrated in serovars of the Canicola, Grippotyphosa, Autumnalis, Australis, Hebdomadis and Pomona serogroups (Alexander et al., 1956; Russell, 1956; Kasărov, 1970). The haemolytic activity of serovar balcanica of the Hebdomadis serogroup has not previously been investigated.

All the balcanica strains studied were haemolytic, although some variation in activity was seen. Similar strain variation has been noted in other haemolytic serovars (Russell, 1956; 
TABLE

Haemolysis of washed and unwashed red blood cells by serovars balcanica, hardjo, pomona and ballum, in a plate haemolytic test

\begin{tabular}{|c|c|c|c|c|c|c|c|c|c|c|}
\hline \multirow{4}{*}{$\begin{array}{c}\text { RBC } \\
\text { donor } \\
\text { no. }\end{array}$} & \multirow{2}{*}{$\begin{array}{l}\text { Material tested } \\
\text { for haemolysis }\end{array}$} & \multirow{2}{*}{$\begin{array}{l}\text { Leptospiral } \\
\text { strain }\end{array}$} & \multicolumn{8}{|c|}{ Zone of haemolysis $(\mathrm{mm})$ on } \\
\hline & & & \multicolumn{4}{|c|}{ washed } & \multicolumn{4}{|c|}{ unwashed } \\
\hline & & & $\operatorname{Ruman}_{\text {RBC }}$ & $\begin{array}{l}\text { bovine } \\
\text { RBC }\end{array}$ & $\begin{array}{l}\text { ovine } \\
\text { RBC }\end{array}$ & $\underset{\text { RBC }}{\text { possum }}$ & $\underset{\text { RBC }}{\text { human }}$ & $\begin{array}{c}\text { bovine } \\
\text { RBC }\end{array}$ & $\begin{array}{l}\text { ovine } \\
\text { RBC }\end{array}$ & $\begin{array}{c}\text { possum } \\
\text { RBC }\end{array}$ \\
\hline & $\left\{\begin{array}{l}\text { Balcanica culture } \\
\text { Hardjo culture } \\
\text { Pomona culture } \\
\text { Ballum culture } \\
\text { Culture medium }\end{array}\right.$ & $\begin{array}{l}\mathrm{a} \\
\mathrm{b} \\
\mathrm{c} \\
\mathrm{d} \\
\mathrm{a} \\
\mathrm{b} \\
\mathrm{a} \\
\mathrm{a} \\
\cdots\end{array}$ & $\begin{array}{l}1 \cdot 2 \\
1 \cdot 0 \\
1 \cdot 2 \\
1 \cdot 5 \\
0 \\
0 \\
1 \cdot 4 \\
0 \\
0^{*}\end{array}$ & $\begin{array}{l}1 \cdot 4 \\
1 \cdot 1 \\
1 \cdot 0 \\
1 \cdot 6 \\
0 \\
0 \\
1 \cdot 6 \\
0 \\
0\end{array}$ & $\begin{array}{l}1 \cdot 4 \\
1 \cdot 3 \\
0 \cdot 6 \\
1 \cdot 2 \\
0 \\
0 \\
1 \cdot 0 \\
0 \\
1 \cdot 0\end{array}$ & $\begin{array}{l}1 \cdot 2 \\
1 \cdot 1 \\
0 \cdot 8 \\
0 \cdot 9 \\
0 \\
0 \\
1 \cdot 0 \\
0 \\
0^{*}\end{array}$ & $\begin{array}{l}1 \cdot 0 \\
0 \cdot 8 \\
0 \cdot 9 \\
1 \cdot 4 \\
0 \\
0 \\
0 \cdot 2 \\
0 \\
0\end{array}$ & $\begin{array}{l}0 \cdot 3 \\
0 \\
0 \\
0 \\
0 \\
0 \\
1 \cdot 2 \\
0 \\
0\end{array}$ & $\begin{array}{l}0 \cdot 3 \\
0 \\
* 0 \\
0 \\
0 \\
0 \\
0 \cdot 5 \\
0 \\
0\end{array}$ & $\begin{array}{l}0 \\
0 \\
0 \\
0 \\
0 \\
0 \\
0 \\
0 \\
0\end{array}$ \\
\hline 2 & $\left\{\begin{array}{l}\text { Balcanica culture } \\
\text { Hardjo culture } \\
\text { Culture medium }\end{array}\right.$ & $\begin{array}{l}\mathrm{a} \\
\mathrm{e} \\
\mathrm{f} \\
\mathrm{g} \\
\mathrm{h} \\
\mathrm{i} \\
\mathrm{a} \\
\mathrm{c} \\
\mathrm{c}\end{array}$ & $\begin{array}{l}1 \cdot 3 \\
0 \cdot 9 \\
0 \cdot 9 \\
0 \cdot 9 \\
1 \cdot 2 \\
1 \cdot 0 \\
0 \\
0 \\
0 \\
0^{*}\end{array}$ & $\begin{array}{l}2 \cdot 0 \\
1 \cdot 4 \\
1 \cdot 0 \\
0 \cdot 9 \\
1 \cdot 7 \\
1 \cdot 5 \\
0 \\
0 \\
0 \\
0\end{array}$ & $\begin{array}{l}\mathbf{N} \\
\mathbf{N} \\
\mathbf{N} \\
\mathbf{N} \\
\mathbf{N} \\
\mathbf{N} \\
\mathbf{N} \\
\mathbf{N} \\
\mathbf{N} \\
\mathbf{N}\end{array}$ & $\begin{array}{l}\mathbf{N} \\
N \\
N \\
N \\
N \\
N \\
N \\
N \\
N \\
N\end{array}$ & $\begin{array}{l}1.2 \\
0.7 \\
0.8 \\
0.7 \\
0.7 \\
0.8 \\
0 \\
0 \\
0 \\
0\end{array}$ & $\begin{array}{l}0 \\
0 \\
0 \\
0 \\
0 \\
0 \\
0 \\
0 \\
0 \\
0\end{array}$ & $\begin{array}{l}\mathbf{N} \\
\mathbf{N} \\
\mathbf{N} \\
\mathbf{N} \\
\mathbf{N} \\
\mathbf{N} \\
\mathbf{N} \\
\mathbf{N} \\
\mathbf{N} \\
\mathbf{N}\end{array}$ & $\begin{array}{l}\mathbf{N} \\
\mathbf{N} \\
\mathbf{N} \\
\mathbf{N} \\
\mathbf{N} \\
\mathbf{N} \\
\mathbf{N} \\
\mathbf{N} \\
\mathbf{N} \\
\mathbf{N}\end{array}$ \\
\hline
\end{tabular}

Kmety and Bakoss, 1961; Chorvath, 1975). All strains used in the present study had been recently isolated; serial subculturing for more than a year sometimes resulted in a partial or complete loss of haemolytic activity. The use of laboratory strains by the earlier workers referred to above may have contributed to the observed variation in haemolytic activity.

Hardjo cultures were non-haemolytic on blood-agar plates, and in the tube test the degree of haemolysis of washed human RBC produced by such cultures was less than that produced by sterile culture medium. Hodges (1974) similarly found New Zealand hardjo strains to be non-haemolytic. The inability of hardjo to haemolyse human and bovine RBC may serve as the basis for a simple in-vitro test for the differentiation of hardjo and balcanica. The most consistent results were obtained with washed human RBC and the maximum haemolytic activity of cultures was found to occur at the peak of leptospiral growth. The test was not significantly affected by blood group.

A haemolytic effect, usually incomplete, was produced on washed RBC by sterile culture medium. This reaction was completely inhibited by the presence of leptospires in the culture medium; hardjo and ballum cultures were non-haemolytic on plates on which culture-medium reactions were seen. No explanation is readily apparent. There were no significant differences in the osmolarity of culture medium that had supported the growth of 7-day hardjo and ballum cultures and that of the sterile control medium.

Infection with leptospires of the Hebdomadis group is endemic in cattle, sheep and possums in New Zealand. The experiments showed that serum antibody was associated with the resistance of the unwashed RBC of some individuals to haemolysis by balcanica. The ability of serum agglutinins to inhibit the haemolytic activity of leptospires has been reported by others (Russell, 1956; Kemenes, 1974). It has also been demonstrated in vitro that haemolysin-inhibit- 
ing antibodies will cross-react with heterologous haemolysins (Alexander et al., 1971; Hodges, 1974).

The differentiation of balcanica and hardjo by their action on human RBC cannot be regarded as definitive. Nevertheless it may be useful in screening large numbers of Hebdomadis serogroup isolates in countries such as New Zealand, where experience has shown that Hebdomadis serogroup isolates are likely to be either hardjo or balcanica.

\section{SUMMARY}

Leptospira interrogans serovar balcanica was haemolytic for washed human, cattle, sheep and possum red blood cells (RBC); serovar hardjo was non-haemolytic. A test for haemolysis may prove useful in the preliminary differentiation of balcanica and hardjo isolates. Balcanica was non-haemolytic for unwashed RBC from human and bovine donors whose serum contained Hebdomadis serogroup antibody. Haemolytic activity tended to disappear with repeated subculture of balcanica.

We wish to thank the Women's Division of Federated Farmers and the Accident Compensation Commission for financial support, and Mrs Lyn Bell and Ms Barbara Wilton for technical assistance.

\section{REFERENCES}

Alexander, A. D., Smith, O. H., Hiatt, C. W. and Gleiser, C. A. 1956. Presence of hemolysin in cultures of pathogenic leptospires. Proc. Soc. exp. Biol. Med., 91. 205.

Alexander, A. D., Wood, G., Yancey, F., Byrne, R. J. and Yager, R. H. 1971. Cross-neutralization of leptospiral hemolysins from different serotypes. Infect. Immun., 4, 154.

BABUDIERI, B. AND MATEEW, D. 1961. Serological study of some Bulgarian strains of Leptospira. Rc. Ist. sup. Sanità, 24, 614 (in Italian).

Chorvath, B. 1975. Some properties of leptospiral haemolysin. Biologia, Bratisl., 30, 460.

Cole, J. R., Sulzer, C. R. ANd Pursell, A. R. 1973. Improved microtechnique for the leptospiral microscopic agglutination test. Appl. Microbiol., 25, 976.

COMmUNiCABle Diseases Center. 1966. Zoonoses surveillance; leptospiral serotype distribution lists. US Department of Health Education and Welfare: Atlanta.

Communicable Diseases Center. 1973. Zoonoses surveillance; leptospiral serotype distribution lists, suppl. 1966-73. US Department of Health Education and Welfare: Atlanta.

Durfee, P. T. AND Presidente, P. J. A. 1977. Isolation of Leptospira interrogans serotype balcanica from a bush-tailed opossum (Trichosurus vulpecula). Aust. vet. J., 53, 508.

Ellis, W. A. AND Michna, S. W. 1977. Bovine leptospirosis. Experimental infection of pregnant heifers with a strain belonging to the Hebdomadis serogroup. Res. vet. Sci., 22, 229.

Hathaway, S. C., Blackmore, D. K. and Marshall, R. B. 1978. The serologic and cultural prevalence of Leptospira interrogans serovar balcanica in possums (Trichosurus vulpecula) in New Zealand. J. wildl. Dis., 14, 345.

Hathaway, S. C. AND Marshall, R. B. 1979. Experimental infection of sheep with Leptospira interrogans serovars hardjo and balcanica. N.Z. vet. J., 27, 197.

Hellstrom, J. S. 1978. Studies on some aspects of the epidemiology of bovine leptospirosis. Ph.D. Thesis, Massey University, Palmerston North, New Zealand.

HoDGes, R. T. 1974. Bovine leptospirosis: the detection of haemolysin inhibitors in sera from experimentally and naturally infected cattle. N.Z. vet. J., 22, 239.

Johnson, R. H., Allan, P. J. And DennetT, D. P. 1974. Association of Leptospira hardjo with abortions in a group of heifers. Aust. vet. J., $50,325$.

KASǍROV, L. B. 1970. Degradation of the erythrocyte phospholipids and haemolysis of the erythrocytes of different animal species by leptospirae. J. med. Microbiol., 3, 29.

KemenEs, F. 1974. Biological characteristics of haemolysin from Leptospira pomona. Folia. Fac. Med. Univ. Comenianae Bratisl., 12. suppl., 1974. 
KMETY, E. AND BAKoss, P. 1961. Hämolysin-und lipaseproduktion bei leptospiren verschiedener serotypen. Zentbl. Bakt. ParasitKde, I. Abt. Orig., 181, 503.

Manev, C. AND Siromashkova, M. 1970. Comparative studies on antigen extracts from some Bulgarian leptospira strains. Zentbl. Bakt. ParasitKde, I. Abt. Orig., 213, 516.

RusSELl, C. M. 1956. A "hemolysin" associated with leptospirae. J. Immunol., 77, 405.

Semenova, L. P., Soloshenko, I. Z. And Ananyin, V. V. 1965. Leptospira of the Hebdomadis group. Report III. Detection of Leptospira sejroe balcanica subtype in the Soviet Union. Zh Mikrobiol. Epidem. Immunobiol., 4, 61 (in Russian). 